12. Gray J: Aeromonas in the gut. Journal of Infection 1987, 15: 197-200.

13. Gästrin B, Kallings LO, Marcetic A: The survival time for different bacteria in various transport media. Acta Pathologica et Microbiologica Scandinavica 1968, 74: 371-380.

14. Popolf M, Véron M: A taxonomic study of the Aeromonas hydrophila-Aeromonas punctata group. Journal of General Microbiology 1976, 94: 11-22.

15. Isenberg HD, Washington JA, Balows A, Sonnenwirth AC: Collection, handling and processing of specimens. In: Lennette EH; Balows A, Hausler WJ, Shadorny HJ (ed): Manual of clinical microbiology. Amcrican Socicty for Microbiology, Washington, DC, 1985, p. $73-98$.

16. Phillips E, Nash P: Culture media. In: Lennette EH, Balows A, Hausler WJ, Shadomy HJ (ed): Manual of clinical microbiology. American Society for Microbiology, Washington, DC, 1985, p. 1051-1092.

\section{Penicillium marneffei Infection in an AIDS Patient}

A 47-year-old homosexual man, who was HIV antibody positive, was admitted to the Department of Internal Medicine of the University Hospital Rotterdam-Dijkzigt with a history of several weeks of daily spiking fever $\left(39^{\circ}-40^{\circ} \mathrm{C}\right)$. Five months before admission he had travelled in rural Thailand. Physical examination revealed an enlarged liver and spleen. $X$-ray of the thorax showed a mild diffuse infiltrate. Investigations (tests for malaria and leishmania, blood cultures, serological tests etc.) revealed no infectious origin. Bronchoalveolar lavage revealed no microbial pathogens.

As a sudden and rapid deterioration in the neurological condition of the patient was noted, a computed tomography scan of the brain was performed and revealed an enhancing mass with a diameter of about $4 \mathrm{~cm}$. Empiric therapy for suspected toxoplasmosis infection was started, consisting of pyrimethamine and sulfadiazine. A liver biopsy yielded one Penicillium colony that initially grew at $26^{\circ} \mathrm{C}$. This fungus was identified as Penicillium marneffei strain Segretain. A sero-precipitin test performed by means of immunodiffusion with Penicillium marneffei as antigen was positive. This result was obtained by courtesy of A.S. Sekhon, National Reference Centre for Human Mycotic Diseases, Provincial Laboratory of Public Health, University of Alberta, Canada (1).

Therapy with amphotericin $B$ and flucytosine was started. The same day, broth culture of a cerebrospinal fluid sample revealed staphylococci. As a result of this finding, flucloxacillin was added to the patient's therapeutic regimen. Despite therapy the patient died one day later. Staphylococcus aureus was cultured from the cerebrospinal fluid post mortem.
Autopsy revealed moderate growth of Staphylococcus aureus in the above-mentioned cerebral mass, lungs and liver. Microscopic examination of sputum and lung tissue showed Pneumocystis carinii. Histopathological examination of lung and liver tissue showed the presence of filaments of Penicillium marneffei, and this organism was cultured from lung tissue. We conclude that the patient was infected with several opportunistic pathogens. Penicillium marneffei has been described as an opportunistic pathogen in patients in Southeast Asia (2). It is regarded as the only pathogenic Penicillium species (R.S. Samson, unpublished data), although some other Penicillium species have been reported as pathogens (3). Our isolate was probably not responsible for the rapid deterioration and sudden death in this patient, although case reports have indicated that this fungus can be a cause of progressive disease or ultimate death in AIDS patients $(4,5)$.

\section{M. J. Hulshof ${ }^{1}$ \\ R. A. A. van Zanten ${ }^{1}$ \\ J. F. Sluiters ${ }^{2}$ \\ M. E. van der Ende ${ }^{1}$ \\ R. S. Samson ${ }^{4}$ \\ P. E. Zondervan ${ }^{3}$ \\ J. H. T. Wagenvoort ${ }^{2 *}$}

${ }^{1}$ Department of Internal Medicine, ${ }^{2}$ Department of Clinical Microbiology, and ${ }^{3}$ Department of Pathology, University Hospital Rotterdam-Dijkzigt, Dr. Molewaterplein 40, 3015 GD Rotterdam, The Netherlands.

${ }^{4}$ Centraalbureau voor Schimmelcultures, Oosterstraat 1 , 3742 SK Baarn, The Netherlands.

\section{References}

1. Sekhon AS, Li JSK, Garg AK: Penicillosis marneffei: serological and exoantigens studies. Mycopathologia 1982, 77: 51-57.

2. Jayanetra $\mathbf{P}$, Nitiyanant $P$, Ajello $L$, Padhye AA, Lolekha S, A tichartakarn V, Vathesatogit P, Sathaphatayavongs B, Prajaktam R: Penicillosis marneffei in Thailand: report of five human cases. American Journal of Tropical Medicine and Hygiene 1984, 33: 637-644.

3. Mori $\mathbf{T}$, Matsumura M, Kohara $T$, Watanabe $\mathbf{Y}$, Ishiyama $T$, Wakabayashi $Y$, Ikemoto $H$, Watanabe A, Tanno M, Shirai T, Ichinoe M: A fatal case of pulmonary penicilliosis. Japanese Journal of Medical Mycology 1987, 28: 341-348.

4. Piehl MR, Kaplan RL, Haber MH: Disseminated penicilliosis in a patient with acquired immunodeficiency syndrome. Archives of Pathology and Laboratory Medicine 1988, 112: 1262-1264.

5. Ancelle $T$, Dupony-Camet $J$, Pujol $F$, Nassif $X$, Ferradini L, Choudat L, de Brieve C, Dupont B, Drouhet E, Lapierre $\mathbf{J}:$ Un cas de penicilliose dissemince a Penicillium marneffei chez un malade atteint d'un syndrome immunodeficitaire acquis. Presse Médicalc 1988, 17: 1095-1096. 